\title{
SS18/SSX2 Fusion Gene
}

National Cancer Institute

\section{Source}

National Cancer Institute. SS18/SSX2 Fusion Gene. NCI Thesaurus. Code C99395.

A fusion gene that results from a chromosomal translocation $t(X ; 18)(p 11.2 ; q 11.2)$ which fuses exon 10 of the SS18 gene to exon 6 of the SSX2 gene. This fusion is associated with synovial sarcoma. 